\title{
AIRSA
}

AKSA: JURNAL DESAIN KOMUNIKASI VISUAL

ISSN: 2615-1111 (online)

Available online at:

JURNAL DESAIN KOMUNIKASI VISUAL

http://aksa.stsrdvisi.ac.id

\section{TINJAUAN MAKNA PADA LABEL KOREK API PROPAGANDA JEPANG DI INDONESIA TAHUN 1942-1945}

\author{
Lintang Dewi Prasistiya ${ }^{1}$, Donna Carollina ${ }^{2}$
}

${ }^{1}$ Sekolah Tinggi Seni Rupa dan Desain Visi Indonesia

${ }^{2}$ Sekolah Tinggi Seni Rupa dan Desain Visi Indonesia

E-mail: milintang@gmail.com ${ }^{1}$, donnacarollina@yahoo.com ${ }^{2}$

\begin{tabular}{ll}
\hline ARTICLE INFO & ABSTRAK \\
\hline Article history: & Japanese propaganda matchboxes is one of the propaganda media \\
Received: 1 September 2019 & used by Japan in its effort to get the hearts and attention of \\
Accepted: 12 September 2019 & $\begin{array}{l}\text { Indonesian people. This matchbox is producted on 1942-1945 with } \\
\text { varied themed on each series, this research will spesifically discuss }\end{array}$ \\
Keywords: & about series 101. As a propaganda media, this matchbox \\
Japanese Propaganda & unconsciously is one of visual communication design product from \\
Wood Lighter & the illustration, message delivery to the audience through design and \\
Meaning & its own function as a packaging. Thus, this research was conducted \\
Art Critism & to reveal the meaning behind the design of the Japanese propaganda \\
& matchbox series 101. \\
& The research of meaning in this qualitative research is carried out \\
& with an approach to art critism according to Edmund Burke \\
& Feldman. The result of this research is the design of Japanese \\
& propaganda matchbox series 101 was produced in 1994 and \\
designed by Takashi Kono. If assessed in term of quality, the visual & element in this lable is harmoniously arranged and create a \\
balanced and unified design. The color has a high contrast, the \\
typography used is san-serif which has high readability and \\
legibility, and the object of illustration is made as closely as possible \\
to the actual object so it can be easily understood. \\
All the visual elements displayed on the design has a connection with \\
the main theme and purpose of this matchbox label is to restore \\
Indonesian people trust because on 1944, Japan situation in \\
battlefield is getting worse and there's a rumor that Japan has \\
defeated in the war, with some hope that they will get Indonesian \\
people trust again and Indonesian people have some initiative to \\
help Japan in the war. Compare to the previous series of the \\
matches, this series emphasize the atmosphere of war and victory in \\
war over America, Britain and China.
\end{tabular}




\section{PENDAHULUAN}

Sekitar tahun 1850 ditemukan teknologi yang dapat menghasilkan korek api pertama. Swedia adalah negara produsen korek api dalam skala besar pertama dan pada pertama kalinya pula desain pada kotak korek api digunakan. Desain kotak korek api awalnya seragam untuk meyakinkan kualitas komparatif produksi, namun pada zaman revolusi industri berkembang menjadi sarana branding. Lalu korek api berubah menjadi hal yang modis dan menarik, korek api turut berkembang seiring dengan perkembangan zaman. Fungsi desain kotak korek api lainnya adalah sebagai sarana propaganda, contohnya adalah korek api propaganda Jepang yang diproduksi pada tahun 1942-1945.

Korek api propaganda Jepang memiliki puluhan nomor seri yang berbeda dan disebarkan di beberapa negara Asia Tenggara dan tentu saja Indonesia. Label korek api yang digunakan dalam propaganda Jepang memiliki nilai lebih karena adanya nilai sejarah yang melatarbelakanginya. Belum ada literatur tentang keberhasilan penggunaan korek api sebagai media propaganda namun bila dilihat dari fungsi korek api secara umum, korek api adalah salah satu keperluan pokok masyarakat Indonesia pada saat itu.

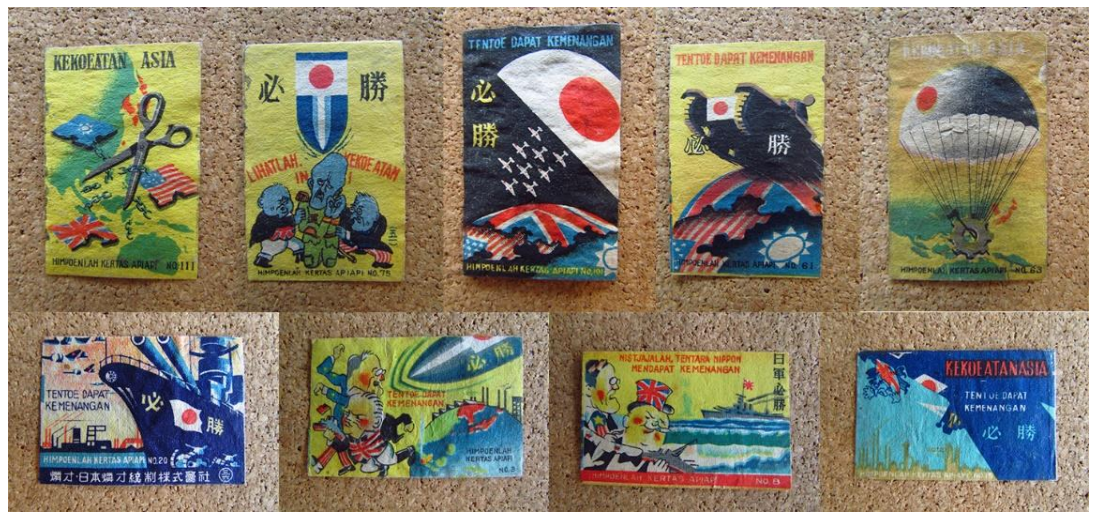

Gambar 1. Label Korek Api Propaganda Jepang pada Perang Dunia II

(Sumber: http://arnon-reisman.blogspot.com/2012/10/here-are-my-ww2-japanese-propaganda.html diakses pada 26 Maret 2019 pukul 19.48)

Propaganda ini ditujukan pada seluruh lapisan masyarakat Indonesia dan beberapa negara di Asia Tenggara lainnya sehingga pesan dan maknanya harus dapat diterima dan dipahami di negara lain walau slogannya menggunakan bahasa Indonesia. Makna dari korek api propaganda Jepang dipandang memiliki urgensi untuk dikaji sebagai salah satu produk Desain Komunikasi Visual. Hanya ada sedikit bentuk fisik label korek api propaganda Jepang yang berhasil diselamatkan dan hingga saat ini belum ditemukan penelitian yang secara khusus mengkaji korek api propaganda Jepang di Indonesia sebagai produk desain 
komunikasi visual. Pada penelitian ini, desain label korek api yang akan ditinjau adalah label kotak korek api propaganda Jepang pada Perang Dunia ke-II dengan nomor seri 101 yang disebarkan di wilayah Asia Tenggara pada tahun 1942-1945.

Berangkat dari pemaparan tersebut, maka dapat dirumuskan rumusan masalah dari penelitian ini adalah (1) Bagaimana bentuk keseluruhan dari korek api propaganda Jepang seri 101 yang meliputi bahan, bentuk, warna, ukuran, dan desain yang ada pada korek api tersebut? (2) Apa makna yang terkandung dalam desain label korek api propaganda Jepang seri 101 ?

Untuk dapat mengungkap makna dalam desain label korek api propaganda Jepang seri 101 teori pendekatan yang digunakan adalah kritik seni menurut Edmund Burke Feldman. Kritik seni rupa adalah pengetahuan teoritis dan cara menilai suatu karya seni yang dilakukan perseorangan baik secara lisan maupun tulisan dan kemudian hasilnya dipublikasikan secara umum. Sedangkan hasil dari kritik seni rupa adalah opini pengamat tentang kualitas suatu karya seni dengan menggunakan dasar teori yang mendukung (Bangun, 2001: 3). Dalam prosesnya, kritik seni dibagi menjadi 4 tahapan yaitu: (1) Tahap Deskripsi; (2) Tahap Analisis Formal; (3) Tahap Interpretasi; (4) Tahap Evaluasi.

Tahap Deskripsi dalam kritik seni merupakan tahapan penggambaran karya seni dengan kata-kata apa adanya, tanpa adanya pendapat. Setelah itu karya seni dianalisis secara keseluruhan dengan dukungan data, tahapan ini adalah analisis formal. Karya dijelaskan secara objektif tanpa adanya dukungan data dari seniman. Tahapan selanjutnya adalah interpretasi, hal yang terdapat di balik karya ditafsirkan dengan mengungkap hal terkait dengan karya seperti gagasan, latar belakang sosial budaya, unsur psikologis dan sebagainya. Pada akhirnya, tahapan evaluasi merupakan penilaian berdasarkan data yang didapatkan dari tahapan deskripsi, analisis dan interpretasi. Karya seni yang dikritik dapat dinilai dengan cara membandingkan dengan karya lainnya yang sejenis.

\section{METODOLOGI}

Metode yang digunakan adalah metode penelitian deskriptif kualitatif dengan teori utama Kritik Seni menurut Edmund Feldman Burke. Teori kritik seni kemudian dikolaborasikan dengan menggunakan beberapa teori pendukung untuk membantu proses deskripsi, analisis, interpretasi dan evaluasi. Hasil temuan selanjutnya dianalisis dengan teknik analisis deksriptif. 


\section{PEMBAHASAN}

\subsection{Tahap Deskripsi}

Deskripsi merupakan tahapan awal yang penting dalam tahapan kritik seni. Korek api propaganda Jepang seri 101 merupakan salah satu dari sekian korek api yang diproduksi oleh Jepang di Indonesia pada tahun 1942-1945. Ada kemungkinan besar untuk korek api seri 101 ini diproduksi dan diedarkan pada tahun 1944 (Antariksa, wawancara 10 Mei 2019). Menurut salah satu artikel di majalah Soeara Asia, korek api pada masa penjajahan Jepang dijual seharga F. 110,- per $1 \mathrm{~kg}$.

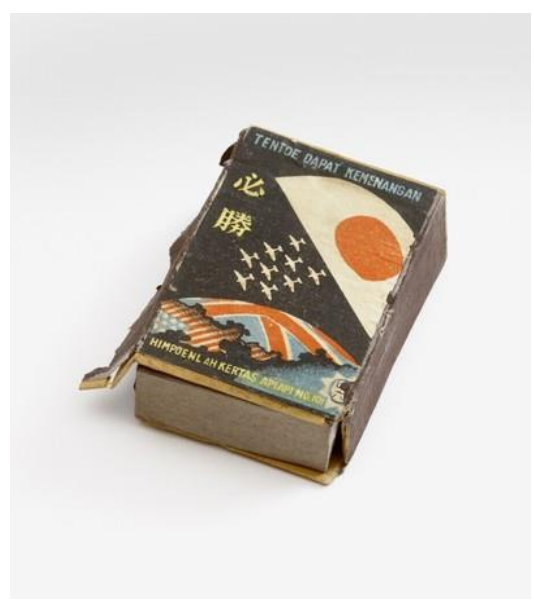

Gambar 2. Korek api propaganda Jepang seri 101

(Sumber: Koleksi Museon Den Haag Belanda)

Media yang digunakan adalah kotak kemasan korek api dengan dimensi 5 x 3,6 x $1,8 \mathrm{~cm}$. Ukuran ini didapatkan dari ukuran-ukuran kotak kemasan korek api yang pada umumnya beredar pada periode tahun 1920-1945 di Indonesia. Berdasarkan pada, kemasannya menggunakan bahan veener kayu yang kemudian disusun sedemikian rupa menjadi struktur yang menyerupai laci. Lalu kotak kayu dilapisi dengan kertas yang digunakan untuk menggesek korek api, dan pada bagian atas dan bawah ditempelkan label berbahan kertas merang dengan desain propaganda Jepang

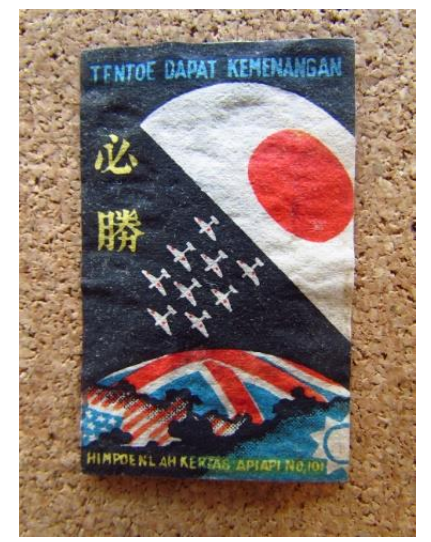


Gambar 3. Label korek api propaganda Jepang seri 101

(Sumber: Koleksi Museon Den Haag Belanda)

Elemen visual pada label korek api propaganda Jepang ini disusun dalam format portrait dengan perbandingan 2:3. Warna yang digunakan adalah warna biru, merah, dan kuning yang merupakan warna primer dan warna hitam yang merupakan presentase hitam/gelap, perpaduan warna ini merupakan laras warna kontras triad komplemen. Terdapat ilustrasi pesawat yang sedang terbang dalam formasi diatas objek berbentuk bulat dan pada objek tersebut terdapat bendera Amerika, Inggris dan Republik Cina yang terbagi menjadi tiga dan dipisahkan dengan garis beraster, pada bagian belakang formasi pesawat digambarkan satu objek setengah lingkaran dengan Hinomaru, atau lambang matahari pada bendera Jepang..

Pada bagian atas desain terdapat tipografi teks "TENTOE DAPAT KEMENANGAN" dengan warna biru, pada bagian bawah tulisan tersebut sebelah kiri tertuliskan kanji 必勝 berwarna kuning, yang dibaca sebagai hisshou. Kanji pertama 必berarti “pasti” dan kanji kedua 勝 berarti “menang”. Jika digabungkan menjadi kalimat "kemenangan yang pasti". Dan terakhir di bagian paling bawah desain terdapat tipografi teks “HIMPOENLAH KERTAS API-API NO. 101" dengan huruf kapital dan warna kuning. Tipografi yang digunakan dalam desain label korek api propaganda Jepang seri 101 ini adalah san-serif. Teks "TENTOE DAPAT KEMENANGAN" dan teks "HIMPOENLAH KERTAS API-API NO. 101" dikomposisikan secara rata tengah (centered). Ukuran teks “TENTOE DAPAT KEMENANGAN" lebih besar dari "HIMPOENLAH KERTAS APIAPI NO. 101”. Untuk kanji 必勝 menggunakan font kanji yang tebal atau bold.

Pada korek api propaganda Jepang seri 101 elemen dominan yang mampu menjadi emphasis atau daya tarik utama adalah objek setengah lingkaran dengan Hinomaru yang merupakan bendera negara Jepang dan kanji 必勝, yang dibaca sebagai hisshou. Sequence pada ilustrasi label korek api propaganda Jepang seri 101 adalah sequence spiral, dapat disimpulkan dari penggunaan penekanan dan penggunaan warna pada desain. 


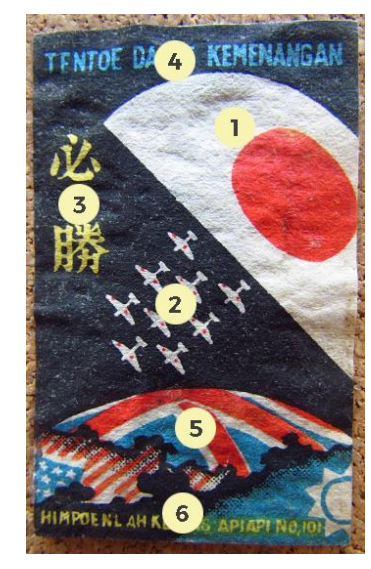

Gambar 5. Sequence label korek api propaganda Jepang seri 101

(Sumber: Dokumentasi penulis)

\subsection{Tahap Analisis Formal}

Tahapan analisis formal merupakan tahapan lanjutan dari tahap deskripsi, pada tahapan ini objek yang dikritik dijelaskan dengan dukungan data dan bukti yang ada di lapangan sebagai upaya untuk menganalisis karya secara kritis (Bangun, 2000: 14). Warna biru, merah, hitam dan kuning yang digunakan dalam label korek api propaganda Jepang seri 101 adalah warna yang mudah didapatkan dalam campur warna proses cetak. Ilustrasi sembilan pesawat dengan Hinomaru di sayap kanan kiri pesawat yang sedang terbang dalam formasi memiliki kemiripan dengan formasi yang diterapkan dan pesawat tempur Jepang pada Perang Dunia II. Pesawat tempur yang memiliki kemiripan dengan ilustrasi ini adalah pesawat tipe The Ki-115, Kawasaki Ki-10, Kawasaki Ki-61, Mitsubishi A5M, Nakajima Ki27, Mistubishi B5M, dan Yokosuka MXY-7 Ohka

Latar belakang dari desain label korek api adalah warna hitam yang kaitannya yang erat dengan malam hari dan kegelapan. Hal ini memiliki korelasi dengan taktik perang pada masa Perang Dunia II yaitu penyerangan dan pertempuran udara malam hari. Selanjutnya benda bulat yang ada di sebelah kiri bawah, ada kemungkinan benda tersebut merupakan representasi dari bumi. Bumi tersebut memiliki gambar tiga bendera yang terbagi yaitu bendera Amerika, Inggris dan Cina. Garis pembagi antar tiga negara ini cenderung tidak rapi dan memiliki efek bayangan, dapat ditafsirkan kalau tiga negara tersebut mengalami kehancuran yang digambarkan dengan terbakar.

Ilustrasi yang menyerupai parasut pada label korek api propaganda Jepang seri 101 memiliki korelasi dengan penyerangan pesawat tempur Jepang yang melepaskan bom dengan parasut. Dan jika dilihat ilustrasi pada label korek api propaganda Jepang seri 63, ada kemungkinan besar kalau objek berbentuk setengah lingkaran berwarna putih dengan Hinomaru merupakan representasi dari parasut. 


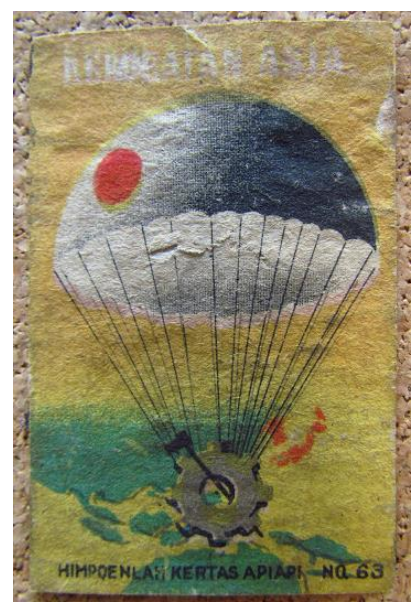

Gambar 6. Korek api propaganda Jepang seri 63

(Sumber: Koleksi Museon Den Haag Belanda)

Hinomaru dikibarkan pertamakali saat merayakan kemenangan Jepang atas Perang Cina-Jepang pertama dan Perang Rusia-Jepang. Dalam situasi perang, bendera juga dikibarkan di seluruh penjuru Jepang. Jika korek api propaganda Jepang seri 101 ini diproduksi pada periode tahun 1942-1945, ada kemungkinan besar korek api ini dibuat untuk memperingati kemenangan Jepang atas perang Cina-Jepang pertama karena pada saat itu Jepang juga sedang berperang dalam perang Cina-Jepang kedua.

Teks tipografi “TENTOE DAPAT KEMENANGAN" merupakan slogan yang digunakan Jepang dalam desain label korek api propaganda dalam beberapa desain label korek api seri lainnya, yaitu seri 3, seri 18, seri 20, seri 61 dan seri 67.

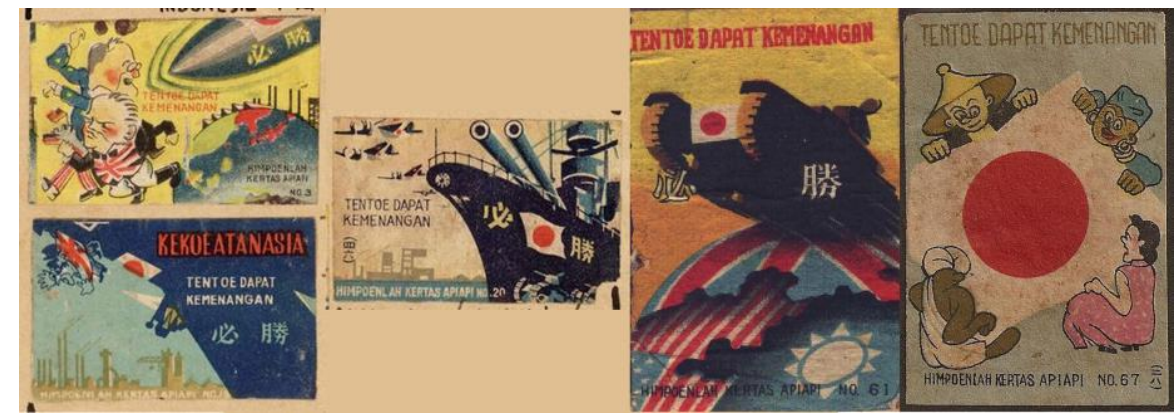

Gambar 7. Label korek api dengan slogan "TENTOE DAPAT KEMENANGAN" (Sumber: Koleksi Museon Den Haag Belanda)

Penggunaan kanji 必勝 berwarna kuning, yang dibaca sebagai hisshou yang merupakan slogan atau kata-kata motivasi dan penyemangat tradisional Jepang, digunakan untuk menggambarkan seseorang yang bertekad untuk menang atau bertekad untuk berhasil. Hisshou adalah satu dari beberapa slogan tradisional yang paling terkenal di Jepang dan slogan ini masih digunakan hingga saat ini sebagai penyemangat. 
Teks tipografi "HIMPOENLAH KERTAS APIAPI NO.101" memiliki kemiripan dengan Gambar Oemboel atau Umbul. Umbul adalah permainan yang sangat terkenal pada periode 1940-an hingga 1980-an. Gambar umbul adalah hasil adaptasi atau metamorphosis dari kartu rokok atau kartu wayang, dalam bahasa Inggris kartu ini disebut cigarette cards. Maka asumsi lainnya adalah, label pada korek api ini mengadaptasi dari kartu rokok dan gambar umbul, karena adanya kesamaan mulai dari struktur dan tujuan penggunaan.

\subsection{Tahap Interpretasi}

Pada tahapan ini, dilakukan tafsir pada hal-hal yang terdapat di balik sebuah karya, dan menafsirkan makna, pesan, atau nilai yang dikandungnya (Feldman, 1967 : 4). Dalam melihat makna pada desain label korek api propaganda Jepang seri 101, dilakukan tinjauan terhadap penanda yang terlihat. Ditinjau dari latar belakangnya, karya desain ini dibuat sebagai salah satu upaya Jepang dalam melakukan propaganda di daerah Kemakmuran Asia Timur Raya. Desain label korek api propaganda Jepang seri 101 menggambarkan skemenangan Jepang melawan Amerika, Inggris dan Cina. Tema ini memiliki kecocokan dengan tema utama propaganda pada setiap tahun yaitu kepercayaan penduduk kepada Jepang di tahun 1944 dan ada kecocokan dengan situasi Jepang di medan perang yang mulai kalah dan merugi pada tahun tersebut.

Tahun 1944 Jepang berada di situasi yang buruk dan rakyat Indonesia mulai ragu akan kemenangan Jepang di perang. Atas dasar krisis yang melanda, muncul satu kebutuhan untuk meningkatkan kepercayaan rakyat Indonesia kepada Jepang dan tetap pada keinginan awal yaitu rakyat Indonesia ikut terlibat dalam perang. Kedua masalah inilah yang memiliki korelasi paling erat dengan latar desain label korek api propaganda Jepang seri 101. Tujuan dari desain label korek api propaganda Jepang seri 101 ini menjadi jelas, yaitu menepis persepsi kalau Jepang akan kalah dan meningkatkan kepercayaan rakyat Indonesia sehingga tidak ada perlawanan.

Situasi yang digambarkannya pun sesuai dengan apa yang dihadapi Jepang pada tahun tersebut. Pada tahun 1944 perang Cina-Jepang kedua masih berlangsung, pasukan Amerika mengirimkan serangan terus menerus dan berhasil mengusir Jepang dari beberapa daerah kependudukannya, sekutu mulai berhasil masuk ke Indonesia dan mengusir Jepang dari wilayah kependudukannya di negara lain. Di negara Jepang sendiri terjadi penyerangan oleh Inggris dan Amerika.

Penggunaan ilustrasi pesawat pada desain label korek api propaganda Jepang seri 101 juga memiliki korelasi dengan Armada Udara Jepang pada tahun 1944. Pada tanggal 25 Oktober 1944, strategi kamikaze untuk pertama kalinya digunakan dalam pertempuran ganas 
Teluk Leyte dengan Amerika. Kamikaze adalah kesatuan penerbang bunuh diri dengan cara menabrakan pesawat ke pesawat dan kapal perang musuh, dimana strategi ini dipandang lebih efektif (Baskara, 2015: 83-84). Sejak itulah, strategi kamikaze sering digunakan dan membuat Perang Asia-Pasifik semakin ganas.

Hinomaru yang digunakan pada objek ilustrasi yang menyerupai parasut mendukung pesan mengenai kemenangan Jepang dalam melawan Amerika, Inggris dan Cina. Jepang memiliki kebiasaan untuk mengibarkan bendera hinomaru dalam merayakan kemenangan atau merayakan suatu hal lainnya yang menggembirakan. Objek parasut dipilih karena parasut memiliki ikatan yang paling dekat dengan ilustrasi pesawat, dan dalam Perang Asia-Pasifik Jepang menggunakan bom parasut untuk menyerang musuh.

Untuk penggunaan slogan “TENTOE DAPAT KEMENANGAN” sudah digunakan sejak label korek api propaganda Jepang seri 3 dan jika dilihat dari koleksi label korek api propaganda Jepang milik museum Museon Den Haag Belanda, seri paling akhir sebelum seri 101 yang menggunakan slogan "TENTOE DAPAT KEMENANGAN” adalah label korek api propaganda Jepang seri 67.

Dari kelima seri label korek api propaganda Jepang, dapat dilihat adanya kesamaan tema dan penggambaran. Yang pertama adalah penggunaan kanji 必勝 yang dibaca sebagai hisshou, lalu adanya kecenderungan untuk menonjolkan kecanggihan armada perang dan kemakmuran negara Jepang. Pada seri 3, 18, 20, dan 61 menggunakan objek ilustrasi utama berupa kapal perang dan tank perang, hal ini memiliki kesamaan dengan seri 101 yang menunjukkan pesawat tempur Jepang. Dan terakhir pada seri 61 digambarkan bendera melengkung dengan urutan bendera Inggris di paling atas, bendera Amerika dibawah sebelah kiri dan bendera Republik Cina dibawah sebelah kanan, penggambaran ini memiliki kesamaan dengan seri 101.

\subsection{Tahap Evaluasi}

Tahap evaluasi atau penilaian adalah tahap terakhir setelah dilakukannya deskripsi, analisis dan interpretasi. Tahapan ini merupakan pertimbangan akan karya seni dengan mempertimbangkan sisi negatif dan postif dari karya (Marianto, 2011: 57-58). Seperti yang dituliskan oleh Aiko Kurasawa, tema utama tahun anggaran propaganda dibuat mulai tahun 1943-1945. Karena korek api propaganda Jepang menggunakan bahasa Indonesia maka diasumsikan korek api propaganda Jepang ini dibuat dan diproduksi di Indonesia pada periode tersebut. Untuk mempersempit tema dan demi didapatkan evaluasi yang lebih tajam, maka desain label korek api seri 101 akan dikaitkan dan dibandingkan 
dengan desain korek api seri lainnya yang menggunakan slogan "TENTOE DAPAT KEMENANGAN".

Jika korek api propaganda diproduksi tahun 1943 maka dapat disesuaikan dengan korek api propaganda Jepang seri 3 sebagai seri paling tua untuk label korek api propaganda dengan slogan "TENTOE PASTI MENANG", dan tema yang paling sesuai adalah Gagasan tentang lingkungan Kemakmuran bersama Asia Timur Raya. Untuk label korek api propaganda Jepang seri 101, diasumsikan diproduksi pada tahun 1944 dimana pada saat itu situasi sedang tidak baik untuk Jepang. Seri label korek api propaganda Jepang paling muda yang dikoleksi oleh museum Museon Den Haag Belanda adalah seri 111, pada seri 111 memiliki slogan "KEKOEATAN ASIA" dengan ilustrasi gunting yang memutus rantai di atas pulau-pulau lingkungan Kemakmuran bersama Asia Timur Raya. Dapat dikatakan pada pembuatan label korek api propaganda Jepang seri 111 masih menggunakan tema utama anggaran propaganda tahun 1944 yang bertemakan kepercayaan penduduk kepada Jepang. Karena pada akhir tahun 1944 dan awal tahun 1945, Amerika dan Inggris mulai menyerbu negara-negara yang diduduki oleh Jepang.

Untuk label korek api propaganda Jepang diasumsikan diproduksi pada tahun 1944 karena mulai dari label korek api propaganda Jepang seri 61, desain dan ilustrasi memiliki kecenderungan lebih menuju ke arah tema utama tahun anggaran propaganda 1944 yang bertemakan kepercayaan penduduk kepada Jepang. Label korek api propaganda Jepang seri 61 dan seri 101 memiliki kesamaan, yaitu adanya penggunaan ilustrasi yang menyerupai bumi dengan ilustrasi bendera Amerika, Inggris dan Cina diatasnya. Tercatat ada kurang lebih tiga pemberontakan di Indonesia yang terjadi selama tahun 1944, rakyat Indonesia mulai merasa gelisah dan ragu akan Jepang. Selain keraguan, rakyat Indonesia juga mulai menolak dan berani untuk melakukan perlawanan atas "Japanisasi”.

Kejadian penyerangan dan pemberontakan yang dilakukan oleh rakyat Indonesia ini menjadi satu indikasi penyebab adanya tema kepercayaan rakyat pada tema utama tahun anggaran propaganda 1944. Tujuan dan fungsi dari pembutan desain label korek api propaganda Jepang seri 101 adalah untuk mempropaganda rakyat Indonesia yang tidak berada di tempat kejadian penyerangan oleh Amerika dan Inggris atau daerah pemberontakan. Korek api ini juga berguna untuk menutupi kabar buruk mengenai Jepang mulai kalah di perang yang beredar di kalangan rakyat dan tentara Jepang sendiri karena dunia pers terbilang lesu di Indonesia pada zaman pendudukan Jepang sehingga semua yang 
disiarkan di Indonesia hanya yang baiknya saja (dalam wawancara dengan tour guide Monumen Pers Nasional Surakarta pada 11 Juni 2019).

Jika dibandingkan dengan label korek api propaganda Jepang seri 61, memang ada kesamaan dan jika ditinjau dari sejarahnya pada perang Cina Jepang kedua, Jepang lebih banyak mengerahkan tentara angkatan daratnya sehingga penggunaan ilustrasi tank dapat ditelusuri alasannya. Dan jika dibandingkan secara visual kedua seri ini dibuat dengan gaya dan teknik yang sama, berbeda dengan seri label korek api propaganda Jepang 67. Pada seri ini lebih menunjukkan tentang keberagaman suku dan keberagaman figure manusia yang merepresentasikan rakyat dari negara yang diduduki oleh Jepang. Gaya gambarnya pun juga berbeda, maka dapat diasumsikan untuk seri 67 dibuat oleh orang yang berbeda dan gaya ini sering ditemui dalam beberapa rubrik ilustrasi majalah Djawa Baroe.

Desain label korek api propaganda Jepang seri 101 tidak terlalu menyimpang jauh dari label korek api propaganda Jepang seri sebelumnya, karena masih memiliki tema yang sama dan latar belakang yang sama. Pesan dan tujuan dikemas dengan sangat baik oleh desainer yang diasumsikan adalah Takashi Kono. Penggunaa warna kontras yang tinggi membuat desain label korek api propaganda Jepang seri 101 cukup menarik, dan perpaduan warnanya juga harmonis karena menerapkan warna triad komplementer. Kekontrasan warna ini membantu untuk mengidentifikasi unsur visual yang ada di desain label korek api.

Evaluasi secara kualitas produksi memang belum dapat dilakukan karena penulis belum melihat bentuk fisik dari korek api propaganda Jepang seri 101, maka penulis hanya dapat melakukan secara visual. Label korek api propapaganda Jepang seri 101 memadukan unsur-unsur rupa dengan baik sehingga tercipta suatu komposisi yang harmonis. Hasil desain label korek api propaganda Jepang seri 101 ini menunjukkan kekhasan dari desainernya sendiri yaitu Takashi Kono. Semua unsur tersusun secara seimbang dan memiliki irama, pembagian proporsi memberikan kesan yang baik sehingga semua unsur visual dalam desain label korek api propaganda Jepang seri 101 memiliki hubungan satu sama lain dan dapat dipahami. Penekanan unsur visualnya juga sesuai dengan pesan dan tujuan dari pembuatan korek api propaganda Jepang ini dan yang terakhir desain ini tetap dijaga kesederhanaannya dan tidak terlalu rumit untuk dipahami.

Desain label korek api propaganda Jepang seri 101 dapat dikatakan sebagai produk desain komunikasi visual, karena desain label korek api propaganda Jepang seri 101 adalah desain yang bertujuan untuk mengkomunikasikan informasi dan pesan secara visual dan tujuan dari desain ini adalah untuk memberikan suatu pengaruh kepada kebanyakan 
orang yang menjadi target dari propaganda Jepang. Dalam desain ini juga menggunakan kekuatan bahasa visual sebagai kekuatan utamanya sebagai suatu alat untuk menyampaikan kemenangan Jepang di medan perang serta untuk meningkatkan dan mengembalikan kepercayaan rakyat Indonesia kepada Jepang.

Sebagai suatu kemasan pun desain label korek api propaganda Jepang seri 101 ini memiliki sifat fleksibel untuk diterima oleh rakyat Indonesia yang sifatnya dinamis pada zaman itu. Secara material dan produksi, korek api propaganda Jepang ini sudah memenuhi standarnya karena memiliki bentuk dan struktur yang sama dengan kemasan korek api pada umumnya. Yang menjadi pembeda kualitas adalah desainnya, dimana desain dari label korek api propaganda Jepang seri 101 ini sudah berhasil menjadi sarana estetika untuk berkomunikasi dengan rakyat Indonesia dengan berbagai latar belakang, minat dan pendidikan yang berbeda.

\section{KESIMPULAN}

Kesimpulan pertama mengenai proses pembuatan dan produksi korek api propaganda Jepang seri 101, desain ini diasumsikan dibuat oleh Takashi Kono yang merupakan ketua bagian seni rupa Keimin Bunka Shidôso. Menurut tema propaganda tahun anggaran dan situasi perang, korek api ini diproduksi pada tahun 1944. Label korek api dicetak diatas kertas merang dengan ukuran dimensi 5 x 3,6 x 1,8 cm dan untuk kemasannya menggunakan veener kayu dengan struktur laci.

Tema utama dari pembuatan desain label korek api propaganda Jepang seri 101 adalah untuk mengembalikan kepercayaan rakyat Indonesia karena pada tahun 1944, keadaan Jepang memburuk dan mereka mulai sadar akan kalah dalam perang. Maka dengan pembuatan korek api propaganda ini ada harapan akan tumbuhnya kepercayaan lagi dan muncul inisiatif untuk membantu Jepang dalam perang. Korek api ini juga sebagai alat untuk menepis desas desus bahwa Jepang kalah dalam perang dengan Inggris, Amerika dan Cina.

Desain label korek api propaganda Jepang ini juga memiliki korelasi dengan beberapa seri korek api lainnya, yaitu seri 3, 18, 20, 61 dan 67. Kelima seri ini memiliki slogan yang sama dengan yaitu "TENTOE DAPAT KEMENANGAN" dan penggunaan kanji 必勝 yang dibaca sebagai hisshou. Pada kelima seri korek api propaganda Jepang ini ada penekanan pada kecanggihan armada perang dan kemakmuran negara Jepang. Secara desain, desain label korek api propaganda Jepang 101 tidak mengalami perubahan kualitas 
namun secara tema pada seri 101 lebih menekankan pada suasana perang dan kemenangan atas perang dengan Amerika, Inggris dan Cina.

Warna yang digunakan adalah warna triad komplemen yang juga merupakan warna proses cetak. Warna dari masing-masing objek memiliki kekontrasan yang tinggi sehingga dapat dikenali dengan mudah. Objek ilustrasi yang digunakan adalah ilustrasi realis. Ilustrasi didominasi oleh bendera Jepang pada objek parasut sebagai tanda akan kemenangan dan kegembiraan, ilustrasi pesawat untuk menandakan strategi pesawat yang sedang digunakan secara intensif pada perang tahun 1944, ilustrasi bumi dengan bendera Amerika, Inggris dan Cina yang terbakar untuk menggambarkan situasi buruk yang menimpa ketiga negara tersebut. Tipografi yang digunakan adalah san-serif yang memiliki readability dan legibility yang tinggi. Semua unsur visual dikomposisikan secara harmonis.

Sebagai suatu kemasan, korek api ini telah mencapai suatu hasil yaitu kualitas sebagai kemasan. Karena kemasan korek api ini menjadi satu sarana estetika untuk berkomunikasi dengan rakyat Indonesia dengan berbagai latar belakang pada zaman itu, dimana rakyat Indonesia masih memiliki tingkat pendidikan yang rendah. Maka dapat dikatakan desain label korek api propaganda Jepang ini telah berhasil sebagai salah satu produk desain komunikasi visual baik dari segi estetika maupun fungsinya sebagai alat propaganda dan sebagai kemasan dari produk korek api itu sendiri.

\section{DAFTAR PUSTAKA}

Bahari, Nooryan. 2008. Kritik Seni Wacana: Wacana Apresiasi dan Kreasi. Yogyakarta: Pustaka Pelajar

Bangun, Sem C. 2001. Kritik Seni Rupa. Bandung: Penerbit ITB

Baskara, Nando. 2015. Kamikaze; Aksi Bunuh Diri "Terhormat" Para Pilot Jepang. Yogyakarta: Media Pressindo

Kardinata, Hanny. 2016. Desain Grafis Indonesia dalam Pusaran Desain Grafis Dunia. Jakarta: DGI Press

Kinser, Maggie. 2004. Matchibako: Japanese Matchbox Art of the 20s and 30s. United States of America: Mark Batty Publisher

Klimchuk, Marianne dan Sandra A. Krasovec. 2006. Desain Kemasan. Diterjemahkan oleh Bob Sabran. Jakarta: Erlangga

Kunandar, Alip. 2017. Memahami Propaganda, Metode, Praktik dan Analisis. Yogyakarta: Kanisius

Kurasawa, Aiko. 2015. Kuasa Jepang di Jawa (Perubahan Sosial di Pedesaan 1942-1945). Diterjemahkan oleh Hermawan Sulistyo. Depok: Komunitas Bambu 
Kusrianto, Adi. 2007. Pengantar Desain Komunikasi Visual. Yogyakarta: Andi Offset

Marianto, Dwi. 2002. Seni Kritik Seni. Yogyakarta: Lembaga Penelitian Institut Seni Indonesia

Ricklefs, M.C. 2005. Sejarah Indonesia Modern 1200-2004. Diterjemahkan oleh Satrio Wahono dkk. Jakarta: Serambi

Rustan, Surianto. 2008. Layout, Dasar dan Penerapannya. Jakarta: Gramedia Pustaka Utama

Sanyoto, Sadjiman Edi. 2010. Nirmana Elemen-elemen Seni dan Desain. Yogyakarta: Jalasutra.

Sihombing, Danton. 2001. Tipografi dalam desain grafis. Jakarta: Gramedia Pustaka Utama

Soedarsono, RM. 1992. Pengantar Apresiasi Seni. Jakarta: Balai Pustaka

Sumardjo, Jakob. 2000. Filsafat Seni. Bandung: Penerbit ITB

Sunarto, Suherman. 2017. Apresiasi Seni Rupa. Yogyakarta: Thafa Media

Sunarto, Wagiono. 2013. Gaya Desain - Tinjauan Sejarah. Jakarta: Pascasarjana IKJ.

Susanto, Mikke. 2011. Diksi Rupa: Kumpulan Istilah dan Gerakan Seni Rupa. Yogyakarta: DictiArt Lab.

Sutopo, H.B. 2006. Metodologi Penelitian Kualitatif. Surakarta: Universitas Sebelas Maret

Tinarbuko, Sumbo. 2009. Semiotika Komunikasi Visual. Yogyakarta: Jalasutra

Winarko, Ibnu. 2018. Gambar Oemboel Tjerita. Yogyakarta: Oemah Oemboel

\section{Jurnal, Skripsi dan Disertasi}

Cenadi, Christine. 1999. Elemen-elemen dalam Desain Komunikasi Visual. Jurnal Nirmana, 1, 111.

Jones, Ben. 2004. Matchbox Cover Design. England: The University of Reading

Putri, Titin Apriani, dkk. 2012. Propaganda Jepang dalam Melancarkan Kebijakan Pendudukan di Indonesia Tahun 1942-1945. Bandar Lampung: Universitas Lampung

Suliyati, Titiek. 2013. Bushido pada masyarakat Jepang: Masa Lalu dan Masa Kini. Semarang: Universitas Diponegoro

Yuliati, Dewi, dkk. 2002. Seni sebagai media Propaganda pada masa pendudukan Jepang di Jawa (1942-1945). Semarang: Universitas Diponegoro

\section{Majalah}

Djawa Baroe, No. 8, 1942

Djawa Baroe, No. 14, 1943

Djawa Baroe, No. 15, 1943

Soeara Asia, 22 Januari 1943

Artikel 
Notes on Air Tactics Used by Japanese by Intelligence Bulletin Desember 1943 dalam http://www.lonesentry.com/articles/jp_airtactics/. Diakses pada 13 Juni 2019 pukul 21.53

Why World War II veterans are returning captured Japanese flags? Januari 2019 dalam https://www.wearethemighty.com/history/world-war-ii-japaneseflag?rebelltitem=1\#rebelltitem1. Diakses pada 27 Juni 2019 pukul 17.39

\section{Webtografi}

Friedman, Herbert. 2017. Strange Gift from Above dalam http://www.psywarrior.com/GiftsFromAbove.html. Diakses pada 3 April 2019 pukul 11.30

Reisman, Arnon. 2012. Here are my WW2 Japanese Propaganda matchbox labels dalam http://arnon-reisman.blogspot.com/2012/10/here-are-my-ww2-japanesepropaganda.html. Diakses pada 26 Maret 2019 pukul 19.48

\section{Video}

Antariksa. 2015. \#DokumentasiIVAA: 3 Setengah Tahun Bekerja - TIM - 2018, Youtube, Jakarta. 1 jam 35 menit

Antariksa. 2015. Arsip Audio Gurafiku 1942-1945, Youtube, Jakarta. 2 jam 17 menit 